\title{
The Formulation Of Community Policing Strategy To Settle Criminal Cases (Within community policing perspective) Dody Eko Wijayanto, ${ }^{1}$ Koesno Adi, ${ }^{2}$ Masruchin Ruba'i, ${ }^{3}$ Prija Djatmika ${ }^{4}$
}

\begin{abstract}
It is stipulated in the Criminal Law that only crime by accusation can be abrogated. On the other hand, common criminal cases must be processed within criminal justice system although it is only a minor legal offense. However, reality shows that minor legal offenses have often been put into a crime trial and community has often reacted against such a practice. This stimulates crime investigators to invent more peaceful ways to settle minor legal offenses although such ways are not acknowledged in criminal laws. Therefore, the Indonesian National Police have searched for a breakthrough to settle minor offenses by applying ADR in the form of penal mediation which puts the formulation of community policing strategy as the leading element ${ }^{5}$.

Key Word : Formulation, Community Policing, Settle Criminal.
\end{abstract}

\section{A. Background of the Problem}

According to the Cartesian Newtonian's view (proposed by Isaac Newton and Rene Descartes), the positive law must be structured in a Nation. ${ }^{6}$. A sovereign nation needs law because it is needed by the rulers for their interests as well as governing the people. Therefore, law is the symbol of a Nation.

As time goes by, the existing law becomes more and more dogmatic, inelastic, irresponsive and therefore, it does not reflect justice. This is why Satjipto Rahardjo proposes the importance of progressive law which is flexible and located closer to the solution of a problem. ${ }^{7}$ Anton also writes about non-systematic law pointing out how the structured law is not able to settle cases fairly and this has caused the image of law to fade away which finally leads to the rise of the trend known as out- of- court settlement. ${ }^{8}$

In fact, there are ways to settle crime case using out-of-court scheme, they are mediation, conciliation and negotiation. Even the terminology ADR towards penal mediation in order to create "restorative Justice" is popular in the police department. Such a way is recommended to be applied by the police with a view to settle minor offenses without bringing them to the court and applying ADR/ penal mediation instead. On the other hand, reality shows how settlements of some minor cases are carried out, such as, the settlement of the watermelon theft case which is conducted by the Mojoroto precinct, the cacao theft in Subang, the chocolate theft in the East Nusa Tenggara and so on. The trials of those cases in the court have led to riots because people judge that the police have gone too far in processing the cases and consequently create injustice. This creates a public opinion that a corruption case which undermines the Nation is sometimes undetected whereas petty theft must be punished. Such a phenomenon stimulates the community to question whether there is a wiser way to create justice in the country.

\section{B. Formulation of the Problem}

1. What is the foundation for the settlement of the crime case through community policing ?

2. How is the formulation of the community policing strategy in settling criminal case at the investigation level?

\section{Research Method}

\footnotetext{
${ }^{1}$ Kandidat Doctor

${ }^{2}$ Promotor

${ }^{3}$ Co Promotor

${ }^{4}$ Co Promotor

${ }^{5}$ Barda Nawawi Arif, mediasi penal

${ }^{6}$ Lawrence, M Friendman, legal system 1975, p. 15

${ }^{7}$ Satjiptjo Rahardjo, hukum progresif

${ }^{8}$ Anton F Susanto, Ilmu Hukum Non Sistematik, Genta Publishing Yogyakarta, 2010
} 
The research method used in this research is juridical method or normative method. This method is applied to analyze written law from various theoretical aspects, history, philosophy as well as using comparison. All are analyzed from the existing constitution/ the constitution in force, books, scientific journals including other supporting written materials taken from various theories selected through analysis.

\section{Discussion}

1. The Role of Community Policing in the Community Counseling for Security and Order (Binkamtibmas)

Community policing is a part of the grand strategy of Indonesian National Police in order to implement their main duties as the keeper of public security and order, law enforcer, protector, public patron and public servant. There is an essential difference in the implementation of the principal duties of the police in the expired Law Number 28, year 1997 and the existing Law Number 2, year 2002. According to the previous law, the first principal duty of the police is law enforcement, whereas counseling public security and order is the second principal duty. Similarly, when the Indonesian National Police is under the same umbrella with the Indonesian armed forces (ABRI), the Law of the National Defence and Security or the HANKAMNAS Law (Law Number 20, year 1982), Article 30, point (4) stipulated that the principal duties of the National Police are law enforcement, protector, patron and the servant of the community. On the other hand, according to the Article 13 of Law Number 2, year 2002 on the Indonesian National Police, the order of the principal duties of the Indonesian National Police are as follows :

a. The maintenance of public security and order

b. Enforcing laws

c. Community protection, functioning as the community patron and serving the community.

It is further stated in the explanation part that the formulation of the principal duties above does not show the order of the priority. All are equally important. In its implementation, a duty may be chosen as the priority based on the situation in the community. The reason of it is that all duties are carried out simultaneously and they can be put into a combination. Besides, police must observe legal norms, ${ }^{10}$ religious norms, politeness, moral values and respects human rights in the line of their duties. Referring to these principal duties, we can conclude that counseling the public security and order (Binkamtibmas) must be prioritized.

When police practice the explanation above in the field of duty, counseling on public security and order must be prioritized. However, investigation that follows law enforcement will be applied when there is a violation of law.

According to G Peter Hofnagels in criminal policy, solving sosial problem through the application of laws is part of the politics of legal policy or in other words, "taking another legal action responsibly" According to the Article 7, Point 1, Letter J of the Indonesian Law on Criminal Procedure (KUHAP) juncto Article 16, point (1), Letter I of the Law Number 2, year 2002 on the Indonesian National Police, other legal actions must :

a. Not against any laws

b. In proportion to the legal obligation obliging the exercise of the action.

c. Be obedient, make sense and included in the job description.

d. Be reasonably considered based on situation of emergency.

e. Respect human rights. ${ }^{11}$

According to the Article 16, Point (2) and the Article 18, Point (1) of the Law Number 2, year 2002 on the Indonesian National Police, when really needed and in the event of emergency, a police officer is allowed to act on his or her own judgment for the sake of the public. Referring to those stipulations, a police officer can do anything to maintain order in the community. Roscoe

\footnotetext{
${ }^{9}$ Division of Legal Socialization, Law No. 2 year 2002 on the Indonesian National Police pl. 60

${ }^{10}$ Ibid, The Explanation of the Law No. 2 year 2002

${ }^{11}$ Ibid, law on the iNdonesian National Police, p. 65
} 
Pound points out that the goal of the law is the order in the community. ${ }^{12}$ Therefore, the main target is the order in the community. Police as the apparatus of the state who counsels of public security and order is of course expected to make efforts in terms of the techniques and tactics. A technique is a written guidance produced by the high-rank officials of the Indonesian National Police, while tactic is a method in the field of duty which is a habit to act in the right way.

Community policing basically functions as

a. Partnership, means that each police officer on the field must prioritize social approach. They must make friends as many as they can in order to get supports on their field duties.

b. Problem Solving

Community policing has preventive function which is implemented in the problem solution efforts as stipulated in the Article 12 of the Direction of the Chief of the Indonesian National Police Number 7 year 2008 on the basic guidance of the strategy and implementation of community policing in the duty of the police. ${ }^{13}$ Furthermore, it is stipulated that the operational pattern of community policing is the solution effort for problems on security and order disturbances which prioritizes the identification of the problems' root, analysis, decision on the action priority and effective evaluation.

Moreover, the cooperation with the community is also needed and therefore, it is not a momentarily solution of problems. The penal effort made in the legal proceeding is the last resort when persuasive way does not work.

The problem-solving effort is aimed at a social problem having a tendency towards a criminal action. On the other hand, the implementation is in the form of the Partnership Forum of Police and Community or FKPM prioritizing ADR theory. ${ }^{14}$

FKPM is the communication forum between police and the community which is carried out under the agreement to discus social problems. They are problems which need to be solved by the community and the police (officer in charge of the community policing) in order to create condition that can support the success of the police works and the improvement of the people's life quality. ${ }^{15}$

Through the existing FKPM in each village as well as each neighborhood (RT/RW), it is hoped that the prevention of security and order disturbances can be realized.

2. The foundation of the use of community policing in the case settlement

The role of community policing in settling criminal case is not specifically regulated in any laws, but we can look into various existing laws and interpret them for the sake of the law.

As en effort to solve problem, the application of community policing is the search for the more essential meaning beyond the conventional function of policing for solving problems. Referring to the Article 14 Letter $\mathrm{C}$ and Article 2 Letter F, the implementation of Alternative Dispute Resolution (ADR) is a form of the problem solving. On the other side, the foundation of the case settlement through community policing strategy is as follows :

a. According to the Article 3 Point (1) of Law Number 14 year 1970 on the Jurisdiction of Judge, Sheet of the Republic of Indonesia Year 1970 number $74,{ }^{16}$ all courts in Indonesian territory are State Courts and established by law. In its addendum, it is also explained that no other courts organized by non-state institutions are allowed. The out-of-court settlement through reconciliation or mediator (arbitration) is allowed. The basic concept used as reference of the ADR are :

1) From ontological point of view

Discussing something from its ontological point of view means that we have to look into its true essence. Therefore, a problem shall be viewed from its root. A problem arises because of the disturbance in a social interaction that finally leads to the

\footnotetext{
${ }^{12}$ Pieter Mahmut, Penelitian Hukum, p. 6

${ }^{13}$ HQ of Indonesian Policei, The Direction of Indonesian Police Chief No. 7 year 2008 on the Basic Guidance, of Strategy and Implementation of Community Policing in the duty of the police, year 2008.

${ }^{14}$ Ibid, p. 24

${ }^{15}$ Ibid, p. 10

${ }^{16}$ The Explanation of Law No. 30 year 1993 on Arbitration , p. 17
} 
violation of law. Actually, everyone philosophically loves honesty and truth and wants to live peacefully and safely without any disturbances. In that way, public order can be realized. Roscoe Pound points out that the goal of the laws is public order. Thomas Cone also explains that law covers certainty aspect, justice aspect and order aspect. Therefore, to establish public order, a just position must be taken. Justice is needed when there is a problem between two individuals and it can be settled in a way that can be accepted by both parties. There is of course a way to settle a case from the legal process until the court trial. However, some people think that the verdict is not fair and therefore, they continuously fight for justice through the high court until the supreme court. Hence, in my opinion, mediation between the accused and the victim is the best way to choose in order to create Restorative Justice. ${ }^{17}$

2) From Epistemological point of view

To solve a problem, the right way is epistemologically needed. Some ways to settle case outside court includes the use of negotiator, mediator, conciliator as well as arbitrator. ${ }^{18}$

3) From axiological point of view

The advantage of case settlement using non-litigation way/ out-of-court way is that it can be more effective and efficient. It does not take much time and the procedure is simpler. It means the parties involved can see the result as soon as possible. It is efficient in away that all parties can accept the decision and experience the restored justice. (Restorative Justice).

4) From juridical point of view

a) The Law Number 30 year 1999 on Arbitration

This law regulates settlement procedure of the civil law cases using out-of-court way. The Article (6) regulates the implementation of alternative dispute resolution (ADR). It stipulates that parties involving in a civil dispute can use the alternative dispute resolution to settle it as long as there is a goodwill among them. ${ }^{19}$

b) The Law Number 14 year 1970 and Law Number 4 year 2003

The addendum explains that the settlement of cases using out-of-court or arbitration way is allowed, but the decision does not have the executorial power until the court order is issued. ${ }^{20}$

This civil stipulation is the reference used by Barda Nawawi Arif to apply alternative dispute resolution to settle criminal cases. Such a practice is later known as penal mediation.

c) The Law Number 2 year 2002 on the Indonesian National Police

(1) Article 18

This article stipulates police action based on individual judgment or individual discretion. This is the basic for the right policing on the field including functioning as a mediator of a problem.

(2) Article 14, Letter J

This stipulation covers main police duty in serving the community in the temporary absence of the responsible institution and/ or responsible party. This gives basis for the members of the Indonesian National Police to settle problems in the community, including carrying out mediation for various cases.

d) The Direction of the Chief of the Indonesian National Police Number 7 year 2008 This direction covers the role of the Partnership Forum between Police and Community (FKPM) in dealing with social problems that potentially leads to crimes in the form of Alternative Dispute Resolution (ADR)

\footnotetext{
${ }^{17}$ Fair settlement approved by bot parties as explained by the National Detective Chief in a Video Conference at the National Police HQ

${ }^{18}$ The Law No. 2 year 2004 on the settlement cases related to industrial relation

${ }^{19}$ Legal Division, The Law No. 30 year 1999 on Arbitration and Alternative of Case Settlement

${ }^{20}$ Legal Information, The Law No. 14 year 1970 on the Principal Duties of the Court
} 
The effort to invent ADR can be carried out in order to improve the role of community policing beyond its conventional role to settle criminal cases in the form of penal mediation. However, it is the duty of the investigators in charge to implement this

The Direction of the Chief of Indonesian National Police through Radiogram

e) Telegram Message from the Chief of the Detective Department No. ST/11/V/2011 dated May 18, 2011 on the Guidance for ADR Implementation in the Detective Department of the Indonesian National Police

f) Telegram Message from the Chief of the Detective Department No. ST/225/XI/2011 dated November 2, 2011 on the postponement of the ADR practice while waiting for legal regulation on the matter.

g) Telegram Message from the Chief of the East Java Regional Police Number STR/80/I/2012/ ROOPS dated January 30, 2012 on the law enforcement for the cases with little economical value and help the kids by applying restorative justice.

h) The result of the Commanders' Meeting of the East Java Regional Police from 30 January 30 until February 1, 2012 in the Mahameru Hall, East Java Police on the stressing that peace resolution through ADR is more effective.

i) Telegram Message of the Chief of East java Regional Police Number : ST/283/II/2012/Dit Bimas dated February 6, 2012 on cases which are allowed to be processed through ADR :

(1) Violation as stipulated in the third book of the Criminal Law

(2) Light crime cases punishable by three-month imprisonment or maximum fine Rp 7500,- (seven thousands five hundreds rupiah)

(3) Minor crime cases (Lichte Musdrigen) : Article 302 on light torture against animal, Article 352 on light torture against human, Article 364 on minor theft, Article 373 on minor embezzlement, Article 379 on minor fraud, Article 482 on minor fencing, Article 315 on minor defamation

(4) Telegram Message of the East Java Regional Police Number : ST/348/VI/212/Dit Bimas dated June 04, 2012 on the instruction to solve conflicts in the community by applying ADR (Alternative Dispute Resolution)

(5) Letter of the Chief of the Indonesian National Police to all Chiefs of Regional Police Number B/3022/XII/2009/SDE Ops dated December 14, 2009 on the handling of cases by applying ADR (Alternative Dispute Resolution)

(6) Telegram Message of the Chief of the Detective Department Number STR/583/VII/2012 dated August 8, 2012 on handling cases by applying the concept of Restorative Justice. ${ }^{21}$

\section{The Formulation of Community Policing Strategy}

To realize justice having the restorative character, a right method is needed. As we can see from the explanation above, ADR is one way to solve problem. Although ADR is commonly used in civil matters, it can be analyzed and improved in order to settle criminal cases and we can transform it into a more specific term known as penal mediation.

In the line of duty, police discretion theory will lead investigators to the realm of penal mediation. In fact, when a problem still has social character, it can be settled by the community through the FKPM. When a case is already reported to the police, the handling of the case is usually at the hand of the detective unit. In this scheme, the perpetrator approaches the victims to ask for an apology and demand a conciliation. When all parties agree, a senior detective can facilitate the conciliation process. The detective, in this way, acts as the mediator and must stand neutrally. Local leaders, such as the neighborhood leader as well as the chief of a village should

\footnotetext{
${ }^{21}$ Written guidelines for all members of the IndonesianNational Police can be in the form of STR (secret telegram/ surat telegram rahasia), or ST (Telegram/ Surat Telegram), which must be obeyed by the subordinate echelons. It can also be in the form of the Direction of the National Police Chief
} 
witness the process and later a memorandum of the process is made. Prior to the conciliation process, the case must go through the investigation and a report of the investigation must be written. This is aimed at anticipating protest or dissatisfaction against the settlement process.

\section{The comparison of community policing practice in some countries}

a. In a country with common law system : The USA

New York City launches a program known as C-POP (Comunity Police Officer Program) involving 900 out of 16.000 patrol officers. Each precint (there are 75 Police Precints in New York) has 10 officers of C-POP and every officer is assigned to a specific area supported by rapid reaction patrol team. C-POP officers carry out their duty in their own discretion. It is hoped that, in this way, they will be able to be familiar with the area assigned to them and find method on how the police resource can be used to fulfill the policing need. The use of the resource in that way is not according to the instruction from their headquarter. It depends on the need of the community. The program which started in 1986 is very popular.

In Houston, Texas, community policing has two programs. They are the establishment of police stations (each station has 9 rooms in the front) and a program called DART (Directed Area Response Team). DART is similar to the Team Policing in Halifax. All patrol squads are formed involving detectives who cooperate with the general-duty police officers to diagnose outstanding problems in the community. The squads carry out reactive and provocative policing and investigate crimes in the area.

Santa Ana, California, is a city Orange County at the South Los Angeles with a large Hispanic population. Its community policing program covers four police stations occupied by uniformed police. Those officers carry out patrols from these stations The stations also manned by civilian officers responsible for community policing. Although they are not armed, the civilians wear the same uniforms as the police responsible for community policing. The difference is that they have specific badges. These civilians are responsible for various social works related to policing, such as motivated the citizens to prevent crimes. On the other hand, general-duties police carry out street patrol on foot to solve problem in the community. ${ }^{22}$

\section{b. In Singapore as a country with Civil Law System}

Singapore is a model where changes in policing are pioneered and decided by the police. In that case, they want to fundamentally change the public-service system and their effort does not take a long time to gain a success. The Singaporean police look similar to their counterparts in Birmingham, Liverpool and other big cities in England. Before that, reactive policing was applied until 1983 in which policing was focused on a large force of patrol and strict division between general-duties police and detectives.

Changes were developed by the Singaporean police from 1983 until 1989. As the head of the State, Prime Minister Lee Kuan Yew insisted that it was time to learn from the East as there was no more lesson from the West. As the consequence of the effort to learn from the Japanese police system, Singapore has approximately 100 small police stations (police posts) which are adopted from the Japanese Koban system. They apply Japanese style of policing in that way. At the same time, they do not focus on the random system of police patrol. The most interesting aspect is that they only need six years to change the system and it did not exceed the normal police budget. In 1970's, they applied NPP (Neighborhood Police Post) and NPC (Neighborhood Police Centre) which relied on call centre system (telephone) system or policecall system in which the officers came whenever they were called as well as redial-cop policing.

Why does Singapore choose community policing as a policing approach? Because the police has limited ability in tackling security problem. The police do not know when, where a crime will happen and who will do it. They do not know the motive either. Besides, the security matters are not the responsibilities of the police only, but the community is also the stakeholder. It does not mean that the police disengage their responsibility, but they want to do it together with the community.

For that purpose, some steps taken by the Singaporean police are :

\footnotetext{
${ }^{22}$ Sutanto, POImas, Pensil 324 Jakarta
} 
1) Changing individual officers' pereception of policing

2) Building public trust

3) Educating the public in order to make them ready and realized that security aspect is a vital matter and it is important for their life. In the end, it is hoped that public are realized that security matters are also their responsibility.

4) Carrying out activities in order to prevent crimes.

As a communication forum or a forum to build between the police and the community. The forum is also aimed at solving problems in the community and each NPC has CSSP (Crime Safety and Security Program)

\section{c. In Japan who colonized Indonesia once}

Western countries apply community policing because most of their efforts to combat crimes did not succeed. They conducted researches on the preventative-patrol model, rapid reaction against the crime, and conventional crime investigation. It is concluded that those practices are needed, but not enough. Furthermore, the use of high technology also helps the combat against crime, but this does not enough either. Besides, police budget often does not fulfil the need to use high technology. Therefore, it is realized in the western countries that partnership with the community is also needed.

On the other hand, community policing in Asian countries comes from the experiences of the countries carrying out policing with the community. Ther practice shows the orientation to the public. For example, the Japanese policing system comes from the context of militeristic Samurai culture. Japan started community policing using Koban and Chuzaisho system in the era of Meiji. It was in the turning of the 19th century to the 20th century. Koban is the japanese words meaning open box. Generally, Koban refers to the police box or police post which open for 24 hours a day to protect the community. It has square form and glass wall facing the street. Koban is manned by the police working accorting to the shift schedule. There is also a Koban which also functions as the residence of the police. The latter is known as Chuzaisho.

The word which means open also signifies that the police station facilitates free discussions between police and the community. Koban is usually established at an area where there is a high crime rate. As of April 1, 2003, there are 6556 Kobans and 7882 Chuzaisho in all parts of Japan. Another form of Koban in rural area is Chuzaisho which also functions as the residence of the police. Chuzaisho means to live there. This is an open police post in the village. A police officer resides in Chuzaisho which is at the heart of the village. It means that police is present in the community for 24 hours. There is an office for the offficer and there are rooms at the back part supporting the function as the residential place. Both Koban and Chuzaisho manned by police of which duty is full public-service. The Koban system has attracted police in other countries. The system has been imported in some countries, including Brazil and Singapore. The system has been tried in Indonesia, especially in Bekasi area, since 2003. Although the format is difference the basic principles underlying Koban system are also practiced in other countries, such as Australia and the USA.

Japan creates policing of the modern community, but such a policing is a newly introduced term. The japanese system which has been reformulated after the World War II, is based on old traditional element referring to Koban and Chuzaisho. Such a police station is placed in the neighborhood covering six or seven blocs of residential place.

Although the system looks like a communuity policing on every inch of the land, which is the tightest system in the world, the Japanese do not complain about it. They fix the system. The Japanese police never developed systemic relationship-program with the community. However, all Kobans are now required to establish an official council of community counselors in order to get feedback from the community. Moreover, they are now applying an approach which has a closer orientation to the program. Before this, although police officers are assigned to all corners of the community, the gravity is still placed on the law enforcement based on discretion, imposing fine to bicycle with incomplete parts, arresting drunk truck driver, and usually keeping the order on the street. Now, they change the priority towards matters which become public interest instead of those of the interest of the police. 
a. The characters of Koban and Chuzaisho :

- Chuzaisho and koban are located in the community;

- The police are responsible for the daily life of the citizens in trems of peace and security;

- Operate for 24 hours (there is no period of unguarded security);

- Involving in the early stage of all police activities

- As the basic of police activity in the partnership between police and community :

$>$ Understanding the needs of law enforcement; Solving problem; Spreading information on crime prevention.

b. Functions and activities of Koban

- Arresting criminals and preventing crimes;

- The investigation of certain minor crimes and accident investigation (The investigation of serious crimes is carried out by detectives of the city police) ;

- Maintaining good relationship with citizens

- Conducting home visits with the purpose to :

$>$ Get along with citizens, get information about families, listening to the public, search for information about anything related to law enforcement, search for information on criminal activities.

- Encountering with the community:

> Problem-solver groups, spread out information about how to prevent crimes, gaining supports and public participation in controling crime.

As a forum to facilitate communication and settle social problems, each Koban and each Chuzaisho has a council functioning as mediator between police and community. The council is led by a community leader with outstanding attention towards the fulfilment of the needs for security.

\section{The implementation of ADR in some countries}

REGULATION OF PENAL MEDIATION IN SOME COUNTRIES

\begin{tabular}{|c|c|}
\hline Country & Regulation \\
\hline AUSTRIA & $\begin{array}{l}\text { - Regulated through the amendment of the Criminal Procedural Law year } \\
1999 \text { which has been promulgated since January 2000, } \\
\text { At the beginning, diversion is applied for children involved in crimes } \\
\text { through the ATA-J (Aubergerichtlicher Tatausgleich fur jugendliche), } \\
\text { but it is later applied for adults through ATA-E (Aubergerichtlicher } \\
\text { Tatausgleich fur erwachsene) which is actually "victim-offender } \\
\text { mediation" (VOM). } \\
\text { According to the Article 90g of Austrian Criminal Procedural Law. } \\
\text { Prosecutor is allowed to divert a crime case from the court as long as : } \\
\text { 1. The accused admits the crime ; } \\
\text { 2. Agree to compensate for the damage done or other contribution for } \\
\text { repairing the damage as well as willing to refrain from doing the } \\
\text { same crime in the future. } \\
\text { Crimes which are subject to diversion and mediation are: } \\
\text { 1. Punishable by five-year imprisonment or } 10 \text { years in cases } \\
\text { involving children. } \\
\text { 2. It can also be for extremely severe violence, but diversion cannot be } \\
\text { applied if the victim is dead (such as mansiaughter). }\end{array}$ \\
\hline BELGIUM & $\begin{array}{l}\text { a. The act on Penal mediation is promulgated in } 1994 \text { supported by the } \\
\text { guideline on Penal Mediation. } \\
\text { b. The aim of "Penal Mediation" is compensating for the material and } \\
\text { moral damage caused by the crime. However, mediation can also be } \\
\text { carried out when the accused needs therapy or recommended to do } \\
\text { community service. }\end{array}$ \\
\hline
\end{tabular}




\begin{tabular}{|c|c|}
\hline & $\begin{array}{l}\text { c. The prosecutor does not send the case to the court if the accused agree } \\
\text { to give compensation to the victim. } \\
\text { d. At the beginning, it is only for a crime punishable by maximum five- } \\
\text { month imprisonment, but the new stipulation includes crimes } \\
\text { punishable by two-year imprisonment. } \\
\text { e. The procedure is stipulated in the Article } 216 \text { of code of criminal } \\
\text { procedure (10.02.1994). }\end{array}$ \\
\hline GERMANY & $\begin{array}{l}\text { - In 1990, OVA (Offender-Victim Arrangement) is included in the Penal } \\
\text { Code of the Child in general ( } \$ 10 \text { I Nr. } 7 \text { JGG), and declared as "a } \\
\text { means of diversion" ( } \$ 45 \text { II S. } 2 \text { JGG). } \\
\text { - In January 12, 1994, Article 46a is added to StGB (Criminal Law) and } \\
\text { provides opportunity to settle crime case between the perpetrator and } \\
\text { the victim through compensation ( known as Tater-Opter-Ausgleich- } \\
\text { TOA). } \\
\text { Article 46a StGB: if the perpetrator fully compensates for the victim or } \\
\text { compensatse for the largest part of the loss suffered, or really makes an } \\
\text { effort to give compensation, the sentence is possibly reduced or } \\
\text { potentially pardoned. The pardon can only be given for a crime } \\
\text { punishable by maximum one-year imprisonment or } 360 \text { units of daily } \\
\text { fine. } \\
\text { If TOA is applied, the trial must be stopped (s. 153b } \\
\text { stop/Strafprozessord-nung/Criminal Law). }\end{array}$ \\
\hline FRANCE & $\begin{array}{l}\text { - The Law } 4 \text { January } 1993 \text { amended Article of CCP (Code Of Criminal } \\
\text { Procedure) which is developed on the base of the Law } 18 \text { December } \\
1998 \text { and the Law } 9 \text { June 1999: the prosecutor can hold a mediation } \\
\text { between the perpetrator and the victim before making decision on } \\
\text { whether or not prosecuting the accused. } \\
\text { - The essence of the Article } 41 \text { CCP: the prosecutor can carry out penal } \\
\text { mediation (with the approval of victim and perpetrator) as long as it can } \\
\text { compensate for the loss, end the misery and help the rehabilitation of } \\
\text { the perpetrator. } \\
\text { If mediation fails, prosecution is carried out. Article s. } 41 \text { and s. } 41-2 \\
\text { CCP allow the prosecutor to order the perpetrator to give compensation } \\
\text { to the victim (penal mediation) instead of imposing fine or revoking } \\
\text { driving license. The prosecutor can also impose an alternative sanction } \\
\text { in form of sixty-hour social work. This penal mediation replaces the } \\
\text { crime charge. }\end{array}$ \\
\hline POLAND & $\begin{array}{l}\text { - Penal mediation is stipulated in the Article 23a CCP (Code of Criminal } \\
\text { Procedure) and Direction of the Justice Ministry promulgated June 13, } \\
2003 \text { on "Mediation Proceedings in Criminal Matters". } \\
\text { - The court and the judge can take initiative for mediation. The approval } \\
\text { from the victim and the perpetrator function likewise. For this purpose, } \\
\text { they can entrust the case to a reliable institution or a person. The } \\
\text { mediation process takes one month at the latest and the State Treasury } \\
\text { is responsible for the cost. The positive result of the mediation is the } \\
\text { foundation for discontinuing the trial process. } \\
\text { The mediation can be applied for all crimes punishable by less than } \\
\text { five-year imprisonment. Even violent crimes can also be mediated. }\end{array}$ \\
\hline $\begin{array}{l}\text { VIOLENT } \\
\text { CRIME } \\
\text { MEDIATION }\end{array}$ & $\begin{array}{l}\text { - VOM (Victim-Offender Mediation) FOR violent crime is applied in } \\
\text { Austria, Poland, Slovenia, Canada, USA, and Norway } \\
\text { - Domestic violent cases can also be mediated in United States, Austria, } \\
\text { Poland, Denmark and Finland. }\end{array}$ \\
\hline
\end{tabular}




\section{E. Conclusion and Suggestion}

1. Conclusion

From the analysis above, it is concluded that :

a. Community policing as the problem-solving strategy of the Indonesian National Police has certain basis although it is not regulated in laws. This strategy is interpreted from various laws and legal theories.

b. Community policing can be implemented in the form of ADR and afterwards, it is transformed into penal mediation which is preceded by conciliation between both parties in which police act as the mediator.

\section{1) Suggestion}

From the analysis above, the writer suggests that a regulation of the Supreme Court giving guidelines to the police investigator is needed in order to give legal basis for the role as a mediator in addition to the principal roles in law enforcement.

\section{REFERENCES}

Andi Hamzah, SH. Asas-Asas Hukum Pidana. Jakarta : PT. Rineka Cipta, 2004.

Anthon F. Susanto, SH.Mhum, Ilmu Hukum Non Sistematik. Yogyakarta : Genta Publishing, 2010.

Barda Nawawi Arief. Mediasi Penal Penyelesaian Perkara Pidana Diluar Pengadilan. Program Magister Ilmu Hukum Pasca Sarjana UNDIP, 2008.

Bentham, Jeremy. The Principles of Morals and Legislation. Prometheus Books, 1988.

David H. Bayley. Police For The Future (Polisi Masa Depan). Jakarta : Cipta Manunggal, 1998.

Divisi Pembinaan Hukum Polri. Undang-undang Kepolisian Negara Republik Indonesia 2002. Cetakan Kedua Induk Kepolisian RI INKOPPOL 2002.

E., Sumaryono. Etika Profesi Hukum : Norma-norma Bagi Penegak Hukum. Yogyakarta, Kanisus, 1995.

Faal, M., Penyaringan Perkara Pidana oleh Polisi (Diskresi Kepolisian) Pradnya Paramita, Jakarta, 1991.

H. Abdusalam. Sik.SH.MH, Irgen Pol. Drs. DPM Sitompul, SH.MH. Sistem Peradilan Pidana. Jakarta : Restu Agung, 2002.

H. Puntang Moerad B.M,SH. Pembentukan Hukum Melalui Putusan Pengadilan Dalam Perkara Pidana. Bandung : PT. Alumni, 2005.

Hadjon, Philipus M. "Tentang Wewenang Pemerintahan, (Bestuursbevoegdheid)" dalam Pro Justitia XVI (1).

Harry Hamersma. Pintu Masuk Ke Dunia Filsafat. Yogyakarta : Kanisus (Anggota IKAPI), 1980.

Joycelyin M. Pollock. Ethics In Crime and Justice.

Pandu, Yudha., Alternative Dispute Resolution : Written Work to Dr. Gregory Tillet pada Summer Class di University of Western Sydney, 1999.

Peter Mahmud Marzuki, SH. Penelitian Hukum. Jakarta : Kencana Prenada Media Group, 2005.

Rachmad Saffa'at, SH. M.Si. Advokasi dan Alternatif Penyeleaian Sengketa. Malang 